\title{
A Note on the Synthesis of Cholesterol in the
}

\section{Animal Organism}

\author{
B E N G T B O R G T R ÖM
}

Department of Physiological Chemistry, University of Lund, Lund, Sweden

$\mathbf{R}^{\mathrm{s}}$ ecent work has shown that cholesterol is synthesized not only in the liver but also in the extra-hepatic tissues. Srere, Chaikoff, Treitman and Burstein $^{1}$ found cholesterol synthesis from $\mathrm{C}-14$ labeled acetate in the eviscerated rat and in in vitro experiments they demonstrated conversion of $\mathrm{C}-14$ acetate to cholesterol by the following isolated tissues of adult rat: liver, kidney, testis, small intestine and skin. The most rapid synthesis occurred in skin and liver. Srere, Chaikoff and Dauben ${ }^{2}$ had earlier shown the adrenal cortex to be a site for cholesterol synthesis.

The synthesis of cholesterol in the rabbit has been studied by Popjak and Beeckmans ${ }^{3}$ with the aid of deuterium oxide and C-14 acetate. They found the $\mathrm{D}$ and $\mathrm{C}-14$ content of the cholesterol of the small intestine and ovaries higher than that of the liver indicating a synthesis of cholesterol in the former organs. They also found the interesting fact that the specific activity of the free cholesterol was higher than that of esterified cholesterol, being about 1.5 times higher in liver and about 3 times higher in small intestine.

In connection with a study of the metabolism of C-14-1-stearic acid in the rat we have made similar observations. We determined the specific activities of the free cholesterol of liver, small intestine and blood, and of total cholesterol of heart, kidney, lung, brain and carcass at different intervals after peroral administration of C-14-1-stearic acid to adult rats (Table 1). The highest specific activities were found in the free cholesterol of the small intestine, indicating that part of the absorbed stearic acid is degraded in the intestinal mucosa presumable to acetate that is utilized for cholesterol synthesis. The specific activities of the cholesterol of all other organs tested were lower than that of the intestine, the liver having the next highest activity. 
Table 1. Specific activity of free cholesterol in counts per min. after a single peroral administration of $l-C$ 14-stearic acid to rats: 1/20 mmole/sq $\mathrm{dm}^{2}$ body surface. Specific activity $90000 \mathrm{c} / \mathrm{min} . / \mathrm{mg}$ as $\mathrm{BaCO}_{3}$.

Standard deviation in counting $< \pm 7 \%$. Background $20 \mathrm{c} / \mathrm{min}$.

Hours after administration

\begin{tabular}{lrrrrr} 
& 2 & 6 & 12 & 24 & 48 \\
\hline Liver & 8 & 13 & 25 & 39 & 25 \\
Small intestine & 11 & 17 & 34 & 65 & 24 \\
Blood & $(2)$ & 9 & 23 & 38 & 21
\end{tabular}

In another type of experiment we found that the intestinal wall contributed a quantitatively important part of the blood cholesterol via the lymphatic system at least during fat absorption and that part of this cholesterol is synthesized in the intestinal wall from ingested fatty acids.

Two adult rats with the intestinal lymphatics cannulated according to Bollman et. al. ${ }^{5}$ were given C-14 labeled fat and the intestinal lymph was collected for 24 hours. The free and esterified cholesterol were separated on columns of aluminum oxide ${ }^{6}$. After saponification of the esterified cholesterol, the two cholesterol fractions were precipitated as digitonides according to Srere et $a l .{ }^{2}$. and the C-14 acitivities assayed after wet combustion. The results are summarized in Table 2.

Table 2. $C^{14}$ content of esterified and free cholesterol and neutral fat fatty acids of intestinal lymph in rat after peroral administration of $0.5 \mathrm{ml}$ corn oil $+18.0 \mathrm{mg} \mathrm{C} \mathrm{C}^{14}$-l-stearic acid (specific activity $150000 \mathrm{c} / \mathrm{min} . / \mathrm{mg}$ as $\mathrm{BaCO}_{3}$ ). Total administrated activity about $2.7 \cdot 10^{6}$ c/min. Specific activity of the fatty acid mixture after hydrolysis about $7000 \mathrm{c} / \mathrm{min}$./mg as $\mathrm{BaCO}_{3}$.

\begin{tabular}{|c|c|c|c|}
\hline & $\begin{array}{c}\text { Weight } \\
\text { mg }\end{array}$ & $\begin{array}{c}\text { Specific } \\
\text { activity } \\
\text { c/m }\end{array}$ & $\begin{array}{l}\text { Per cent of } \\
\text { administered } \\
\text { activity }\end{array}$ \\
\hline Esterified cholesterol & 6.8 & 109 & 0.027 \\
\hline Free cholesterol & 9.4 & 112 & 0.039 \\
\hline Neutral fat fatty acids & 367 & 5360 & 73.8 \\
\hline Esterified cholesterol & 3.6 & 58.5 & 0.0078 \\
\hline Free cholesterol & 5.8 & 107 & 0.016 \\
\hline Neutral fat fatty acids & 117 & 4050 & 17.5 \\
\hline
\end{tabular}


The findings here reported are in accord with the results of Popjak and Beeckmans ${ }^{3}$ on rabbit and show the active part played by the small intestine in the metabolism of fatty acids and cholesterol. However, Popjak and Beeckmans found higher activities of esterified than of free cholesterol of small intestine. Our figures for intestinal lymph cholesterol show about the same or lower specific activities for esterified cholesterol compared with those for free cholesterol.

This work is part of an investigation supported by a grant from the Medical Faculty of the University of Lund.

\section{REFERENCES}

1. Srere, P. A., Chaikoff, I. L., Treitman, S. S., and Burstein, L. S. J. Biol. Chem. 182 (1950) 629.

2. Srere, P. A., Chaikoff, I. L., and Dauben, W. G. J. Biol. Chem. 176 (1948) 829.

3. Popjak, G., and Beeckmans, M. L. Biochem. J. 47 (1950) 233.

4. Bergström, S., Borgström, B., Carlsten, A., and Rottenberg, M. Acta Chem. Scand. 4 (1950) 1142.

5. Bollman, J. L., Cain, J. C., and Grindlay, J. H. J. Lab. Clin. Med. 33 (1948) 1349.

6. Borgström, B. Acta Chem. Scand. To be published.

Received April 13, 1951. 